\title{
Strengthening International Cooperation for Health and Biodiversity
}

\author{
Kathryn Campbell, ${ }^{1}$ David Cooper, ${ }^{1}$ Braulio Dias, ${ }^{1}$ Anne-Hélène Prieur-Richard, ${ }^{2,3}$ \\ Diarmid Campbell-Lendrum, ${ }^{4}$ William B. Karesh, ${ }^{5,6,7}$ and Peter Daszak ${ }^{3,5}$ \\ ${ }^{1}$ Secretariat of the Convention on Biological Diversity, 413 St. Jacques St. W, Suite 800, Montreal, QC H2Y 1N9, Canada \\ ${ }^{2}$ DIVERSITAS, clo Muséum National d'Histoire Naturelle (MNHN), 57 Rue Cuvier-CP41, 75231 Paris Cedex 05, France \\ ${ }^{3}$ DIVERSITAS ecoHEALTH Cross-cutting Network, c/o EcoHealth Alliance, 460 West 34th Street, New York, NY 10001 \\ ${ }^{4}$ Public Health and Environment Department, World Health Organization, 20 Avenue Appia, 1211 Geneva 27, Switzerland \\ ${ }^{5}$ EcoHealth Alliance, 460 West 34th Street, New York, NY \\ ${ }^{6}$ IUCN Species Survival Commission Wildlife Health Specialist Group, c/o EcoHealth Alliance, 460 West 34th Street, New York, NY \\ ${ }^{7}$ World Organization for Animal Health, Working Group on Wildlife Diseases, 12 Rue du Prony, 75017 Paris, France
}

Biodiversity and health are inextricably linked. Biodiversity underpins the functioning of the ecosystems on which we depend for our food and fresh water and for regulating climate, floods, and diseases. It is a source of medicines (traditional and modern), supports physical and mental wellbeing, offers cultural and spiritual enrichment, and contributes to livelihoods, all of which has benefits for health. Indeed, human health is dependent, directly or indirectly on biodiversity-supported ecosystem services (Secretariat of the Convention on Biological Diversity 2010a).

Knowledge of these links is not new. Our dependence on healthy ecosystems for our own well-being is embedded in many cultures and our reliance continues today even in much-altered environments. The Millennium Ecosystem Assessment demonstrates that health and well-being are broadly dependent on the services provided by biodiversity and ecosystems (Reid et al. 2005; World Health Organization 2005). However, the depth of these linkages is still not fully known, and their positive and negative outcomes

Note to Production: Please copy Managing Editor (Aleksei Chmura: chmura@ ecohealth.net) on Author Proof emails. Many thanks!.

Published online: May 11, 2012

Correspondence to: Peter Daszak, e-mail: daszak@ecohealthalliance.org for human health may be far more significant than previously proposed.

Non-communicable diseases are the leading cause of mortality worldwide, responsible for more than 36 million deaths in 2008 (World Health Organization 2011). The most significant of these (cancer, heart disease, stroke, lung disease, and diabetes) are increasingly being treated with preventative health measures, often called "lifestyle choices." Major benefits for biodiversity can be achieved in parallel with three of the lifestyle choices that improve human health: increasing our dietary diversity promotes awareness of the value of biological diversity for food and nutrition and can lead to the improved protection of species, their genetic diversity and ecosystems; moderating consumption and encouraging more sustainable agriculture, fisheries and forest practices, as well as more sustainable production and use of existing cleared land reduces land clearing and resultant biodiversity loss (Foley et al. 2011); and more regular physical exercise can reduce greenhouse gas emissions, encourage greater appreciation of the environment, and benefit mental, physical, and emotional health as more time is spent in natural settings.

Emerging infectious diseases (EIDs) are perhaps a more direct example of the fundamental linkages between 
biodiversity and health. These diseases include pandemics such as HIV/AIDS, SARS, and a series of influenza strains that have caused significant global mortality, morbidity, and economic loss. If we analyze the anatomy of a pandemic, we see obvious links to biodiversity, primarily because the majority of EIDs are zoonotic, of wildlife origin, and are therefore a product of biodiversity. Indeed, the risk of disease emergence correlates most directly with high global biodiversity and anthropogenic influence (Jones et al. 2008). This has led to public health programs which in some cases attempt to remove wildlife reservoirs of specific pathogens (e.g., badgers for TB or bats for rabies). However, the underlying causes of disease emergence are anthropogenic environmental changes such as changes in land-use, expansion of agriculture, growing global trade in wildlife and livestock, and migration into wildlife habitat (Keesing et al. 2010). We propose that managing these changes provides an ideal strategy to both reduce health impacts and conserve biodiversity.

Biodiversity loss threatens health directly and indirectly by reducing genetic diversity, undermining ecosystem resilience and hampering our efforts to meet the millennium development goals. It is therefore a critical goal for a number of intergovernmental organizations to address the linkages between biodiversity and health (Secretariat of the Convention on Biological Diversity 2010b; DIVERSITAS ecoHEALTH Cross-Cutting Network 2011).

At the international level, the Convention on Biological Diversity (CBD) is a multi-lateral environmental agreement with 192 Member States and the European Union as Parties. At the tenth meeting of the CBD Parties in Nagoya, Japan, October 2010, a new Strategic Plan for Biodiversity 2011-2020 was adopted. The vision is of a world "Living in harmony with nature" where "by 2050, biodiversity is valued, conserved, restored and wisely used, maintaining ecosystem services, sustaining a healthy planet and delivering benefits essential for all people." The Strategic Plan includes 20 headline targets, known as the "Aichi Biodiversity Targets," which can be considered a common framework for action by all stakeholders in all sectors. Health and well-being are recognized in Target 14, which states that "by 2020, ecosystems that provide essential services, including services related to water, and contribute to health, livelihoods and well-being, are restored and safeguarded..." In addition, the achievement of other Targets (e.g., Target 7 that focuses on sustainable agriculture, aquaculture and forestry and Target 9 that concentrates on invasive alien species and pathways) will have direct or indirect impacts on human health and well-being, and the five goals of the Strategic Plan for Biodiversity offer opportunities to maintain and restore healthy and fully functional ecosystems on which we all depend for health. Ultimately, these initiatives will contribute to the conservation and sustainable use of biodiversity, as well as the promotion of a healthier global population.

In October 2010, Parties to the CBD recognized in their decisions the need to further strengthen collaboration with the World Health Organization and with other relevant organizations to: (1) investigate how implementation of the Strategic Plan for Biodiversity can best support efforts to address global health issues; and (2) explore avenues for bridging the gaps between work on climate change impacts on public health and impacts on biodiversity. This would build upon existing close ties with the Food and Agriculture Organization, the World Organization for Animal Health (OIE), and the International Union for Conservation of Nature via a variety of frameworks such as the Inter-Agency Liaison Group on Invasive Alien Species. These goals are also currently advanced through collaboration with the scientific organizations DIVERSITAS and EcoHealth Alliance, through the provision of their scientific guidance to inform efforts that support biodiversity.

The approach and goal of these organizations is to provide sound, science-based evidence on which policy makers can act on the linkages between biodiversity and health. These include a deeper understanding of how environmental changes drive emerging diseases, how biodiversity loss may promote the transmission of some pathogens, and how efforts to deal with non-infectious diseases can promote healthier ecosystems. This underpinning of science draws on the fields of EcoHealth, One Health, Ecosystem Approaches to Health, and Environmental Determinants of Human Health.

We call for two specific actions. First, we call for health and biodiversity professionals to promote greater awareness of the need for a more holistic approach by both sectors with a focus on human physical, mental, and social wellbeing in our environment. Second, we encourage a greater engagement of a broad range of organizations interested in health and biodiversity that will contribute and share their understanding of these essential linkages. By leveraging our partnerships, and tapping into a broad science base, we will generate the innovative solutions that can be adopted by intergovernmental agencies to achieve a healthy planet for healthy people. 


\section{REFERENCES}

DIVERSITAS ecoHEALTH Cross-Cutting Network (2011) ecoHEALTH: A project of DIVERSITAS aiming at exploring links between biodiversity and emerging infectious diseases. www. diversitas-international.org/activities/research/ecohealth. Accessed Mar 19, 2012

Foley JA, Ramankutty N, Brauman KA, Cassidy ES, Gerber JS, Johnston M, et al. (2011) Solutions for a cultivated planet. Nature 478:337-342

Jones KE, Patel N, Levy M, Storeygard A, Balk D, Gittleman JL, et al. (2008) Global trends in emerging infectious diseases. Nature 451:990-994

Keesing F, Belden LK, Daszak P, Dobson A, Harvell CD, Holt RD, Hudson P, Jolles A, Jones KE, Mitchell CE, Myers SS, Bogich T, Ostfeld RS (2010) Impacts of biodiversity on the emergence and transmission of infectious diseases. Nature 468:647-652. doi:10.1038/nature09575
Reid WV, Mooney HA, Cropper A, Capistrano D, Carpenter SR, Chopra K (2005) Ecosystems and Human Well-being: Biodiversity Synthesis, Washington: World Resources Institute

Secretariat of the Convention on Biological Diversity (2010a) Global Biodiversity Outlook 3, Montréal

Secretariat of the Convention on Biological Diversity (2010b) The strategic plan for biodiversity 2011-2020 and the Aichi Biodiversity Targets (Annex to Decision X/2). http://www.cbd.int/sp. Accessed Mar 19, 2012

World Health Organization (2005) Ecosystems and Human Wellbeing: Health Synthesis. Geneva: World Health Organization. http://www.who.int/globalchange/ecosystems/ecosystems05/en/ index.html. Accessed Mar 19, 2012

World Health Organization (2011) Noncommunicable diseases country profiles 2011: WHO Global Report. Geneva: World Health Organization. http://www.who.int/nmh/publications/ncd. profiles2011/en/index.html. Accessed Mar 19, 2012 